\title{
PERSPEKTIF KEADILAN DAN KEPASTIAN HUKUM \\ DALAM PUTUSAN PRAPERADILAN \\ NOMOR: 04/PID.PRAP/2015/PN.JKT.SEL. TAHUN 2015
}

\author{
Oktein Josephus Susak \\ Universitas Nusa Cendana \\ Jl. Adisucipto, Penfui-Kupang \\ E-mail:mooysusak@gmail.com
}

\begin{abstract}
Pretrial arrangement in the Criminal Procedure Code is a strict rule with a clear limitation. One function of pretrial is to test the validity of the initial arrest and detention as a forced effort on behalf of legislation. Pretrial in the formulation of the Criminal Procedure Code is more directed at administrative oversight. In a pretrial ruling No. 04/Pid.Prap/2015/PN.Jkt.Sel., judges have intruded normative boundaries by extending the authority of a preliminary hearing object includes examining "determination of the suspect", although not explicitly mentioned in the Criminal Procedure Code provisions.

The problem in this research is "How is the existence of Criminal Pretrial Case Decision No. 04/Pid.Prap/2015/PN.Jkt.Sel., viewed from the aspect of justice and the rule of law?". This research is a normative juridical approach method using the conceptual approach, case approach and the approach of legislation.

Based on the findings, it was concluded that the examination in pretrial is a voluntair examination as an effort to actualize the procedural justice, but related to a quo case, to realize substantial justice the judges act by entering the "determination of the suspect" as an element of the object of new norms in the series Article 77 letter a Criminal Procedure Code into a pretrial authority. This creates legal uncertainty, since it contradicts with the principle of Lex Specialis Derogat Legi Generalis, Noscitur a Sociis principle, Ejusdem Generis principle and the principle of Expressio Unius Exclusio Alterius. With the model of reasoning methods argumentum a'contrario as one of the construction methods of the law against Article 77 letter a Criminal Code, it is known that the "determination of the suspect" is not a pretrial object. The actions of judges had exceeded its authority, and the logic of the law of the judge in the formation of the new norm object element does not include extensive interpretation but a construction model law by analogy to the method of interpretation is contrary to the principle of legality and is not allowed in criminal law.
\end{abstract}

Key words: analogy interpretation, criminal procedure code, suspect determination, law construction, pretrial

\footnotetext{
Abstrak

Pengaturan praperadilan dalam KUHAP merupakan aturan yang ketat dengan limitatif yang jelas. Salah satu fungsi praperadilan adalah untuk menguji keabsahan proses awal penangkapan dan penahanan sebagai upaya paksa atas nama undang-undang. Praperadilan dalam rumusan KUHAP lebih mengarah pada pengawasan administratif. Dalam putusan Nomor: 04/Pid. Prap/2015/PN.Jkt.Sel., hakim telah menerobos batasan normatif dengan memperluas obyek
} 
kewenangan pemeriksaan praperadilan meliputi pemeriksaan "penetapan tersangka", meskipun secara eksplisit ketentuannya tidak disebutkan dalam KUHAP.

Permasalahan dalam penelitian ini adalah "Bagaimana eksistensi Putusan Perkara Pidana Praperadilan Nomor: 04/Pid.Prap/ 2015/PN.Jkt.Sel., ditinjau dari aspek keadilan dan kepastian hukum?". Penelitian ini merupakan penelitian yuridis normatif dengan metode pendekatan meliputi pendekatan konseptual, pendekatan kasus dan pendekatan perundang-undangan.

Berdasarkan hasil penelitian, disimpulkan bahwa pemeriksaan dalam praperadilan merupakan pemeriksaan voluntair sebagai upaya mewujudkan keadilan prosedural, namun terkait perkara a quo, hakim seolah-olah hendak mewujudkan keadilan substansial dengan memasukkan "penetapan tersangka" sebagai unsur objek norma baru dalam rangkaian Pasal 77 huruf a KUHAP menjadi kewenangan praperadilan. Hal ini menciptakan ketidakpastian hukum, karena bertentangan dengan asas Lex Specialis Derogat Legi Generalis, asas Noscitur a Sociis, asas Ejusdem Generis dan asas Expressio Unius Exclusio Alterius. Dengan model penalaran metode argumentum a'contrario sebagai salah satu dari metode konstruksi hukum terhadap Pasal 77 huruf a KUHAP, diketahui bahwa "penetapan tersangka" bukanlah obyek praperadilan. Tindakan hakim tersebut telah melampaui kewenangannya, dan logika hukum hakim dalam pembentukkan unsur objek norma baru tersebut tidak termasuk penafsiran ekstensif namun merupakan model konstruksi hukum dengan metode interpretasi analogi yang bertentangan dengan asas legalitas dan tidak diperbolehkan dalam hukum pidana.

Kata kunci: interpretasi analogi, konstruksi hukum, KUHAP, penetapan tersangka, praperadilan

\section{Latar Belakang}

Lahirnya Kitab Undang-Undang Hukum Acara Pidana (KUHAP) didasarkan pada 2 (dua) alasan, yaitu untuk menciptakan suatu ketentuan yang dapat mendukung terselenggaranya suatu peradilan pidana yang adil (fair trial) dan adanya urgensi untuk menggantikan produk hukum acara yang bersifat kolonialistik sebagaimana yang tercantum dalam Herzien Inlandsch Reglement (HIR) yaitu belum menjamin dan memberikan perlindungan yang cukup terhadap Hak Asasi Manusia (HAM), ${ }^{1}$ dan tidak adanya pengaturan hukum terkait lembaga pengawasan yang berwenangan menguji keabsahan tindakan aparat penegak hukum dalam pelaksanaan wewenangnya.
Berdasarkan pertimbangan tersebut, lembaga praperadilan hadir sebagai bentuk "pengimbang" antara kepentingan individu (tersangka atau terdakwa) terhadap kewenangan yang diberikan kepada penyidik dan penuntut umum untuk menggunakan upaya paksa dalam pemeriksaan tindak pidana yaitu penangkapan dan/atau penahanan, termasuk penyitaan dan penggeledahan.

Menurut etimologinya, praperadilan terdiri dari 2 (dua) suku kata, yaitu pra dan peradilan. Kata "pra" itu sendiri diartikan sebelum, sedangkan kata "peradilan" diartikan sebagai suatu proses pemeriksaan atas tersangka, saksi-saksi dan barang bukti oleh pengadilan dalam rangka mencari kebenaran 
materiil. ${ }^{2}$ Dengan demikian dapat disimpulkan bahwa praperadilan diartikan sebagai proses pemeriksaan voluntair yang dilakukan sebelum pemeriksaan terhadap pokok perkara berlangsung di pengadilan. Adapun yang dimaksud dengan pokok perkara dalam hal ini adalah suatu dakwaan tentang telah terjadinya suatu tindak pidana, yang sedang dalam tahap penyidikan atau penuntutan. ${ }^{3}$

Lembaga praperadilan di Indonesia mirip dengan lembaga Pretrial di Amerika Serikat, lembaga Rechter Commisaris di Belanda atau lembaga Judge d'Instruction di Perancis. Namun ruang lingkup praperadilan bersifat limitatif sebagaimana yang telah ditentukan dalam Pasal 77 huruf (a) dan (b) KUHAP dan Pasal 95 KUHAP, yaitu hanya terbatas pada: ${ }^{4}$

(1) Memeriksa dan memutus sah atau tidaknya penangkapan atau penahanan;

(2) Memeriksa dan memutus sah atau tidaknya penghentian penyidikan atau penghentian penuntutan;

(3) Memeriksa dan memutus ganti kerugian dan atau rehabilitasi bagi seorang yang perkara pidananya dihentikan pada tingkat penyidikan atau penuntutan;

(4) Memeriksa dan memutus terhadap tuntutan ganti kerugian yang diajukan oleh tersangka atau ahli warisnya atas penangkapan atau penahanan serta tindakan lain tanpa alasan yang berdasarkan undang-undang atau karena kekeliruan mengenai orang atau hukum yang diterapkan;

(5) Memeriksa dan memutus permintaan rehabilitasi yang diajukan oleh tersangka atas penangkapan atau penahanan tanpa alasan berdasarkan undang-undang atau kekeliruan mengenai orang atau hukum yang diterapkan, yang perkaranya tidak diajukan ke Pengadilan Negeri.

Praperadilan adalah satu cerminan pelaksanaan dari asas praduga tidak bersalah (presumption of innocent), dimana tiap orang yang diajukan sebagai tersangka/terdakwa telah melalui proses awal yang wajar dan mendapat perlindungan harkat dan martabat manusianya. ${ }^{5}$

Dalam pengaturan Pasal 77 KUHAP yang dikaitkan dengan Pasal 1 angka 10 KUHAP, secara implisit terdapat 2 (dua) kepentingan yang hendak dilindungi secara seimbang melalui praperadilan, yaitu kepentingan individu (in casu tersangka atau terdakwa) dan kepentingan publik atau masyarakat melalui penegakan hukum.

Dalam proses pemeriksaan permohonan praperadilan terkait penetapan status tersangka Komjen Pol. Drs. Budi Gunawan, S.H., M.Si., oleh Penyidik Komisi Pemberantasan Korupsi (KPK) yang telah diputuskan oleh Hakim

2 Wahyu Januar, Studi Komparatif Hukum Wewenang Dan Fungsi Praperadilan Menurut Hukum Acara Pidana Indonesia Dengan Sistem Habeas Corpus Di Amerika Serikat, (Surakarta: FH. Universitas Sebelas Maret, 2011), hlm. 33.

3 Beatrik Dwi Septiana dkk., Upaya Hukum Atas Putusan Praperadilan Yang Melampaui Kewenangan Lembaga Praperadilan (Studi Kasus Putusan Pengadilan Negeri Jakarta Selatan Nomor: 38/Pid.Prap/2012/PN.Jkt. Sel., Atas Nama Bachtiar Abdul Fatah), (Jakarta: FH. Universitas Indonesia, 2013), hlm. 5.

4 Wahyu Januar, op.cit., hlm. 70.

5 Dian Novita Sari, Pengajuan Praperadilan Oleh Pihak Tersangka Terhadap Sah Atau Tidaknya Penahanan Yang Dilakukan Penyidik Kejaksaan Dalam Tindak Pidana Korupsi (Studi Putusan Nomor.01/PID/PRA. PER/2011/PN.STB.) (Medan: FH. Universitas Sumatera Utara, 2012), hlm. 15. 
Pengadilan Negeri Jakarta Selatan dengan putusan Nomor: 04/Pid.Prap/2015/ PN.Jkt. Sel., menuai kritik di kalangan praktisi hukum maupun akademisi. Putusan a quo dipandang telah menerobos batasan normatif dalam Pasal 77 KUHAP. Hakim dalam perkara a quo memperluas obyek kewenangan pemeriksaan praperadilan yang juga meliputi pemeriksaan "status tersangka" dimana secara eksplisit tidak disebutkan dalam KUHAP. Amar putusan perkara a quo di antaranya adalah sebagai berikut: ${ }^{6}$

(1) Menyatakan surat perintah penyidikan Nomor: Sprindik-03/01/01/2015 tanggal 12 Januari 2015 yang menetapkan pemohon sebagai tersangka oleh termohon terkait peristiwa pidana sebagiamana dimaksud Pasal 12 huruf a atau b, Pasal 5 ayat 2, Pasal 11 atau 12B Undang-Undang Nomor 31 Tahun 1999 tentang Pemberantasan Tindak Pidana Korupsi jo Undang-Undang Nomor 20 Tahun 2001 tentang Perubahan Atas Undang-Undang Nomor 31 Tahun 1999 tentang Pemberantasan Tindak Pidana Korupsi jo Pasal 55 ayat (1) ke-1 KUHP adalah tidak sah dan tidak berdasar atas hukum, dan oleh karenanya penetapan $a$ quo tidak mempunyai kekuatan mengikat;

(2) Menyatakan penyidikan yang dilakukan termohon terkait peristiwa pidana sebagaimana dimaksud dalam penetapan tersangka terhadap diri pemohon sebagaimana dimaksud dalam Pasal 12 huruf a atau b, Pasal 5 ayat 2, Pasal 11 atau 12B Undang-Undang Nomor 31 Tahun 1999 tentang Pemberantasan
Tindak Pidana Korupsi jo UU 20 tahun 2001 tentang Perubahan Atas UndangUndang Nomor 31 Tahun 1999 tentang Pemberantasan Tindak Pidana Korupsi jo Pasal 55 ayat (1) ke-1 KUHP adalah tidak sah dan tidak berdasar atas hukum, dan oleh karenanya penyidikan a quo tidak mempunyai hukum mengikat;

(3) Menyatakan penetapan tersangka atas diri pemohon yang dilakukan termohon adalah tidak sah;

(4) Menyatakan tidak sah segala keputusan atau penetapan yang dikeluarkan lebih lanjut oleh termohon yang berkaitan dengan penetapan tersangka terhadap diri pemohon oleh termohon;

Akibat dari amar putusan hakim praperadilan tersebut, secara hukum status Komjen Pol. Drs. Budi Gunawan, S.H., M.Si., yang semula adalah tersangka menjadi bebas sesuai Pasal 82 ayat (3) KUHAP.

Berdasarkan hal tersebut di atas, permasalahan dari penulisan ini adalah bagaimana makna Putusan Praperadilan Nomor: 04/Pid.Prap/2015/PN.Jkt.Sel., ditinjau dari aspek keadilan dan kepastian hukum?

Tulisan ini dibuat berdasarkan penelitian yuridis normatif dengan metode pendekatan meliputi pendekatan konseptual, pendekatan kasus dan pendekatan perundang-undangan. Analisis bahan hukum dikaji secara preskriptif menggunakan metode penafsiran hukum dan metode konstruksi hukum.

6 Putusan Pengadilan Negeri Jakarta Selatan Nomor: 04/Pid.Prap/2015/PN.Jkt.Sel. tentang Penetapan Tersangka, hlm. 242-243. 


\section{Pembahasan}

A. Putusan Praperadilan Nomor: 04/Pid.Prap/2015/PN.Jkt.Sel., Ditinjau dari Aspek Keadilan dan Kepastian Hukum

Guna membahas aspek keadilan dan kepastian hukum dari perkara a quo, maka logika hakim dalam membentuk pertimbangan hukum merupakan esensi yang harus diperhatikan.

Setiap point pertimbangan hukum hakim praperadilan terhadap perkara a quo dapat dianalisis dengan 2 (dua) metode penemuan hukum yaitu metode penafsiran hukum dan metode konstruksi hukum, antara lain:

1. Terkait dengan metode penafsiran hukum dalam perkara a quo, salah satu jenis penafsiran yang digunakan hakim praperadilan adalah penafsiran ekstensif, yakni hakim melakukan perluasan makna dari ketentuan khusus menjadi ketentuan umum sesuai kaidah tata bahasanya karena maksud dan tujuannya kurang jelas atau terlalu abstrak agar menjadi jelas dan konkrit, perlu diperluas maknanya.

Bertitik tolak dari 2 (dua) metode penemuan hukum yang tersedia, hakim praperadilan memilih metode interpretasi atau penafsiran, dengan alasan untuk menetapkan hukum yang semula tidak jelas menjadi jelas. Alasan pemilihan metode interpretasi atau penafsiran ini mengindikasikan bahwa hakim praperadilan dalam pertimbangan hukumnya berpandangan bahwa pengaturan masalah sah atau tidaknya penetapan tersangka dalam KUHAP dan peraturan perundangundangan pidana lain belum ada atau tidak jelas, sehingga diperlukan interpretasi atau penafsiran terhadap ketentuan yang ada guna memperjelas apakah keabsahan penetapan tersangka termasuk dalam wewenang praperadilan yang diatur dalam hukum positif Indonesia.

Alasan ini tentu sejalan dengan tujuan digunakannya interpretasi atau penafsiran dalam penemuan hukum, yaitu untuk menafsirkan perkataan dalam undang-undang dengan tetap berpegang pada kata-kata/bunyi peraturannya, manakala suatu peristiwa konkrit tidak secara jelas dan tegas dianut atau diatur dalam suatu peraturan perundangundangan. Namun kemudian, alasan digunakannya interpretasi atau penafsiran oleh hakim praperadilan ini bertentangan dengan pertimbangan hukum terdahulu, yang menyatakan: ${ }^{7}$

- Menimbang, bahwa dari rumusan pengertian Pasal 1 angka 10 jo. Pasal 77 jo. Pasal 82 ayat (1) dan ayat (2) KUHAP tersebut dapat diketahui dengan jelas bahwa "sah atau tidaknya penetapan tersangka" tidak termasuk objek praperadilan, karena hal itu tidak diatur; Menimbang, bahwa demikian pula halnya dengan segala ketentuan peraturan perundang-undangan Pidana Khusus yang berlaku sebagai hukum positif

7 Putusan Pengadilan Negeri Jakarta Selatan Nomor: 04/Pid.Prap/2015/PN.Jkt.Sel., op.cit., hlm. $222-223$. 
di Indonesia juga tidak ada ditemukan aturan yang mengatur kalau pengujian tentang "sah atau tidaknya Penetapan Tersangka" menjadi objek praperadilan;

Dalam perkara a quo, hakim praperadilan secara tegas menyatakan dalam pertimbangan hukumnya bahwa sah atau tidaknya penetapan tersangka tidak termasuk obyek praperadilan, dengan alasan bahwa hal tersebut tidak diatur baik dalam KUHAP khususnya Pasal 1 angka 10 jo Pasal 77 jo Pasal 82 ayat (1) jo Pasal 95 ayat (1) dan ayat (2) maupun dalam peraturan perundang-undangan pidana khusus yang berlaku sebagai hukum positif di Indonesia.

Mencermati pertimbangan di atas, dapat dikemukakan jika pertimbangan hukum ini yang dijadikan alasan yakni KUHAP dan peraturan perundang-undangan pidana lain yang ada saat ini belum atau tidak mengatur perihal keabsahan penetapan tersangka sebagai wewenang praperadilan, sehingga bila hendak melakukan penemuan hukum, maka metode yang paling tepat untuk mengisi kekosongan hukum atau ketidaklengkapan undang-undang yang harus diisi atau dilengkapi oleh hakim ini adalah metode konstruksi hukum, bukan metode interpretasi atau penafsiran.

Berdasarkan kedua pertimbangan hukum yang bertolak belakang dengan pertimbangan hukum yang mendasari pemilihan metode penafsiran atau interpretasi ini, menunjukkan ketidakjelasan sikap hakim praperadilan, apakah menurutnya KUHAP dan peraturan perundang-undangan pidana lain yang berlaku saat ini "tidak mengatur" atau "sudah mengatur, tapi belum cukup jelas". Ketidakjelasan sikap ini semakin tampak manakala hakim praperadilan seolah-olah ingin mencampuradukkan antara metode penafsiran dan metode konstruksi dengan menyebut penafsiran penghalusan hukum (rechtvervijning), padahal penghalusan hukum bukan merupakan metode penafsiran melainkan metode konstruksi hukum.

Melalui metode argumentum a'contrario sebagai salah satu dari metode konstruksi hukum, maka hanya hal-hal yang telah ditetapkan secara limitatif dalam Pasal 1 angka 10, Pasal 77 sampai Pasal 82, dan Pasal 95 sampai Pasal 97 KUHAP sajalah yang dapat dimohonkan praperadilan, sedangkan peristiwa atau hal-hal yang tidak diatur dalam hal ini sah atau tidaknya penetapan tersangka - berlaku sebaliknya atau tidak dapat dimohonkan praperadilan karena hal-hal yang tidak diatur tersebut bukan merupakan obyek praperadilan.

Di samping penggunaan metode penemuan hukum yang keliru, argumentasi yuridis hakim praperadilan menjadi tidak jelas dalam menggunakan penafsiran ekstensif sebagai salah satu dari jenis penafsiran dengan menyatakan: ${ }^{8}$

- Menimbang, bahwa segala tindakan Penyidik dalam proses penyidikan dan segala tindakan Penuntut Umum dalam proses penuntutan yang belum diatur dalam Pasal 77 jo. Pasal 82 ayat (1) jo. Pasal 95 ayat (1) dan ayat (2) KUHAP, 
ditetapkan menjadi objek praperadilan dan lembaga hukum yang berwenang menguji keabsahan segala tindakan Penyidik dalam proses penyidikan dan segala tindakan Penuntut Umum dalam proses penuntutan adalah Lembaga Praperadilan;

- Menimbang, bahwa terkait langsung dengan permohonan Pemohon, karena "Penetapan Tersangka"merupakan bagian dari rangkaian tindakan Penyidik dalam proses penyidikan, maka lembaga hukum yang berwenang menguji dan menilai keabsahan "Penetapan Tersangka" adalah Lembaga Praperadilan;

Bahkan, hakim praperadilan sama sekali tidak mengemukakan argumentasi dan alasanalasan yang logis sehingga berkesimpulan bahwa segala tindakan penyidik dan penuntut umum termasuk penetapan tersangka merupakan obyek Praperadilan.

Selain tidak didukung dengan argumentasi yang jelas, memasukan segala tindakan penyidik dan penuntut umum menjadi obyek praperadilan memunculkan banyak pertanyaan terkait dengan ditetapkannya tindakantindakan lain yang dilakukan oleh penyidik dan penuntut umum diluar yang sudah diatur dalam KUHAP sebagai obyek praperadilan. Misalnya, apakah tindakan penyidik seperti menerima laporan atau pengaduan dari seseorang tentang adanya tindak pidana atau mengadakan tindakan lain menurut hukum yang bertanggung jawab sebagaimana diatur dalam Pasal 7 ayat (1) KUHAP dan tindakan penuntut umum seperti mengadakan tindakan lain dalam lingkup tugas dan tanggung jawab sebagai penuntut umum menurut ketentuan undang-undang dan melaksanakan putusan penetapan hakim sebagaimana diatur dalam Pasal 14 KUHAP merupakan obyek praperadilan? Apabila merupakan obyek praperadilan, maka pemberian wewenang tambahan kepada pengadilan negeri untuk melakukan pemeriksaan terhadap kasuskasus yang berkaitan dengan penggunaan upaya paksa (penangkapan, penahanan, penggeledahan, penyitaan, dan lain-lain) yang dilakukan oleh penyidik dan penuntut umum melalui Lembaga Praperadilan tidak bisa lagi dipertahankan mengingat tidak semua tindakan penyidik dan penuntut umum dapat dikategorikan sebagai upaya paksa. Sedangkan menurut Yahya Harahap, tujuan yang ingin dicapai oleh praperadilan adalah untuk melakukan pengawasan horizontal terhadap tindakan upaya paksa yang dilakukan oleh penyidik dan penuntut umum terhadap tersangka maupun terdakwa supaya tindakan tersebut tidak bertentangan dengan ketentuan hukum dan undang-undang.

Lebih jauh, dalam putusan praperadilan ini, kata-kata "penangkapan, penahanan, penghentian penyidikan atau penghentian penuntutan" telah mendapat perluasan makna, sehingga seolah-olah pasca putusan perkara pidana permohonan praperadilan Nomor: 04/ Pid.Prap/2015/PN.Jkt.Sel., dibaca menjadi:

Penangkapan, penahanan, penetapan sebagai tersangka, penghentian penyidikan atau penghentian penuntutan" adalah objek praperadilan.

Pemikiran ini lebih terlihat sebagai bentuk konstruksi daripada sebagai sebuah 
interpretasi. Hal ini dikarenakan dalam Pasal 77 KUHAP menyatakan:

Pengadilan negeri berwenang untuk memeriksa dan memutus, sesuai dengan ketentuan yang diatur dalam undang-undang ini tentang:

(a) Sah atau tidaknya penangkapan, penahanan, penghentian penyidikan atau penghentian penuntutan;

(b) Ganti kerugian dan atau rehabilitasi bagi seorang yang perkara pidananya dihentikan pada tingkat penyidikan atau penuntutan".

Formulasi yang relevan untuk dibahas dalam putusan praperadilan adalah Pasal 77 huruf a KUHAP. Dalam ketentuan huruf a tersebut disebutkan secara eksplisit adanya 4 (empat) tindakan yang dapat diperiksa atau diputuskan keabsahannya. Jadi, apabila hakim praperadilan hendak melakukan penafsiran yang memperluas makna (interpretasi ekstensif) terhadap kata "upaya paksa", hakim praperadilan seharusnya hanya melakukan interpretasi perluasan makna terhadap kata "penangkapan" dan/atau "penahanan" saja. Penetapan tersangka tidak termasuk dalam klasifikasi yang sama dengan klasifikasi penangkapan dan/atau penahanan. Hal ini dikarenakan penangkapan dan/atau penahanan adalah proses awal sebelum seseorang dinyatakan sebagai tersangka. Penetapan sebagai tersangka tidak termasuk sebagai perluasan makna dari kata "penangkapan" dan/atau "penahanan" dan tentunya tidak dapat dikategorikan sebagai "upaya paksa" yang merupakan obyek pemeriksaan lembaga praperadilan. Dengan perkataan lain, seorang penafsir tidak dapat menggunakan penafsiran ekstensif dari kata penangkapan dan/atau penahanan untuk kemudian sampai pada kesimpulan bahwa dari kedua kata itu bisa dimunculkan kata "penetapan tersangka".

Terkait dengan kata "penghentian penyidikan atau penghentian penuntutan", maka sekilas kata-kata tersebut berada dalam satu klasifikasi dengan penetapan tersangka. Kondisi ini dikarenakan "penghentian penyidikan atau penghentian penuntutan" adalah implikasi yang bernuansa kebalikan dari penetapan seseorang sebagai tersangka. Namun, rasio dari Pasal 77 huruf a menjadi kehilangan makna jika kata "penetapan tersangka" disandingkan sebagai perluasan makna dari kata-kata "penghentian penyidikan atau penghentian penuntutan". Alasannya adalah karena spirit atau semangat dari Pasal 77 KUHAP adalah untuk memberi hak bagi seseorang yang tidak bersalah namun sudah terlanjur diperlakukan tidak adil akibat tindakan penyidik yang tidak profesional, yaitu:

- $\quad$ Salah menangkap orang; dan/atau

- Salah menahan orang.

Dalam kasus dugaan gratifikasi yang diperiksa penyidik KPK terhadap Komjen Pol. Drs. Budi Gunawan, S.H., M.Si., jelas tidak ada indikasi adanya 2 (dua) tindakan tidak profesional tersebut telah dilakukan oleh penyidik KPK yaitu salah menangkap orang dan/atau salah menahan orang. 
Kondisi berikutnya adalah soal penghentian penyidikan atau penghentian penuntutan. Hal ini berbeda dengan kondisi pertama (penangkapan dan penahanan). Jika pada kondisi pertama, yang merasa diperlakukan tidak adil adalah orang yang diduga sebagai pelaku tindak pidana, yang kemudian ditangkap dan/atau ditahan secara tidak sah. Sebaliknya, pada kondisi kedua, yang merasa diperlakukan tidak adil adalah si pelapor tindak pidana itu (saksi korban). Dalam konteks ini, jelas kasus yang menimpa Komjen Pol. Drs. Budi Gunawan, S.H., M.Si., tidak relevan untuk dikaitkan dengan kondisi tersebut.

Berdasarkan analisis di atas, maka "penemuan hukum" oleh hakim praperadilan yang memasukkan penetapan tersangka sebagai bagian dari objek yang dapat diproses menurut ketentuan Pasal 77 huruf a KUHAP adalah sebuah kekeliruan, karena hal tersebut berarti bahwa hakim sudah melakukan konstruksi, menambahkan unsur objek norma (normgedrag) baru di dalam rangkaian Pasal 77 huruf a KUHAP. Sementara, penambahan tersebut justru bertentangan dengan rasio yang dibangun oleh rumusan Pasal 77 KUHAP.

Implikasi selanjutnya adalah terkait dengan ketentuan KUHAP lainnya yang berhubungan dengan praperadilan, yaitu Pasal 95 KUHAP. Ruang lingkup Pasal 95 berada dalam konteks yang sama dengan Pasal 77 huruf $b$, yaitu berkaitan dengan ganti kerugian dan rehabilitasi. Kedua pasal ini, Pasal 77 dan Pasal 95 KUHAP harus dibaca dalam satu nafas yang sama. Kata kunci Pasal 95 sebenarnya terletak pada kondisi norma yang dilekatkan pada anak kalimat pada ayat (1), yaitu:

Tersangka, terdakwa atau terpidana berhak menuntut ganti kerugian karena ditangkap, ditahan, dituntut dan diadili atau dikenakan tindakan lain, tanpa alasan yang berdasarkan undang-undang atau karena kekeliruan mengenai orangnya atau hukum yang diterapkan.

Anak kalimat tersebut mensyaratkan bahwa semua tindakan ini (termasuk kata "tindakan lain" yang ditambahkan pada Pasal 95 ayat [1] KUHAP tersebut) harus terlebih dulu dibuktikan memang sudah ada kesalahan, yaitu tidak berdasarkan undang-undang, ada kekeliruan mengenai orang, atau keliru hukum yang diterapkan. Jika tidak ada kesalahan, maka tidak ada alasan untuk memakai Pasal 95 KUHAP guna minta ganti kerugian.

Selanjutnya, kata "tindakan lain" berarti harus juga dibaca dalam kaitan dengan Pasal 77 KUHAP, yakni "ditangkap, ditahan, dituntut dan diadili". Dalam kasus penetapan tersangka terhadap Budi Gunawan, jelas bahwa tersangka Budi Gunawan tidak ditangkap, tidak ditahan, juga belum dituntut dan belum diadili. Dengan demikian, tidak ada relevansinya menggunakan Pasal 95 KUHAP. Hakim praperadilan setuju dengan argumen bahwa walaupun tersangka tidak ditangkap dan tidak ditahan, namun Pasal 77 KUHAP tetap bisa menjangkau tindakan penyidik KPK dikarenakan semua tindakan itu bisa diganti dengan satu kata yang lain, 
yaitu "upaya paksa". Dengan demikian, yang berangkat dari kekosongan hukum, berdasarkan putusan ini, Pasal 77 huruf dapat dikatakan bahwa metode argumentum a KUHAP pasca putusan perkara pidana per analogiam telah digunakannya untuk permohonan praperadilan Nomor: 04/Pid. menarik kewenangan pengujian sah atau Prap/2015/PN.Jkt.Sel., bisa dibaca menjadi sebagai berikut:

Pengadilan negeri berwenang untuk memeriksa dan memutus, sesuai dengan ketentuan yang diatur dalam undang-undang ini tentang: sah atau tidaknya upaya paksa..."

Menyadari hal itu, semua rincian termasuk "tindakan lain" yang ada dalam Pasal 95 ayat (1) KUHAP sekarang menjadi terbuka untuk dimaknai secara seluas-luasnya, yakni semua tindakan yang tergolong upaya paksa. Apa yang dimaksud dengan upaya paksa adalah semua tindakan berlabel pro justitia. Sedangkan pembentuk undang-undang (KUHAP) jelas sekali ingin memberi makna limitatif atas terminologi "tindakan lain" yang ada di dalam Pasal 95. Di mana, dalam penjelasan Pasal 95 ayat (1) KUHAP, frasa "tindakan lain" dijelaskan sebagai tindakan pemasukan rumah, penggeledahan, dan penyitaan yang tidak sah." Formulasinya sudah sangat eksplisit - asas clara non sunt interpretanda - artinya, dalam rumusan itu tidak berdasar untuk memasukkan unsur norma baru dengan mengartikan "tindakan lain" dengan tambahan "penetapan tersangka" atau bahkan lebih luas lagi yaitu "upaya paksa".

Lebih jauh, jika dilihat dari pertimbangan hukum yang digunakan hakim praperadilan

9 Ibid., hlm. 216. 
2. Terkait dengan asas legalitas hukum) tidak dapat menyelesaikan masalah sebagaimana dalam eksepsi Termohon, secara adil atau sesuai dengan kenyataan hakim praperadilan mempertimbangkan sosial (social werkelijkheid). Penghalusan bahwa asas legalitas hanya berlaku dalam hukum merupakan penyempurnaan sistem penerapan Hukum Pidana Materiil, dan tidak mencakup Hukum Acara Pidana yang adalah Hukum Pidana Formil. Bahkan menurut hakim praperadilan bahwa dalam perkembangannya, asas legalitas dalam Hukum Acara Pidana dimungkinkan dilakukan penafsiran dengan pembatasan.

Dalam pertimbangannya, hakim mendasarkan "penafsiran dengan pembatasan" pada 2 (dua) metode penemuan hukum yang sesungguhnya saling berlawanan, yakni dengan menggunakan penafsiran penghalusan hukum (rechtvervijning) yang adalah metode konstruksi hukum dan penafsiran ekstensif (extensieve interpretatie) yang merupakan metode penafsiran.

Penghalusan hukum (rechtsverfijning) adalah memperlakukan hukum sedemikian rupa (secara halus) sehingga seolah-olah tidak ada pihak yang disalahkan. Penghalusan hukum dengan cara mempersempit berlakunya suatu pasal merupakan kebalikan daripada analogi hukum. Penghalusan hukum bermaksud mengisi kekosongan dalam sistem undang-undang. Sistem Undang-Undang dikatakan terdapat ruang kosong apabila hukum oleh hakim. Perbuatan menghaluskan hukum ketika hakim terpaksa mengeluarkan perkara yang bersangkutan dari lingkungan ketentuan dan selanjutnya diselesaikan menurut peraturan tersendiri. ${ }^{10}$

Di sisi lain dalam penafsiran ekstensif (extensieve interpretatie) isi pengertian suatu ketentuan hukum diperluas dengan maksud agar dengan memperluas tersebut, hal-hal yang tadinya tidak termasuk dalam ketentuan hukum tersebut dan belum ada ketentuan hukum lain yang mengaturnya, dapat dicakup oleh hukum yang diperluas tersebut (namun masih berpegang pada aturan yang ada). ${ }^{11}$

Dalam perkara a quo, memasukkan "penetapan tersangka" sebagai obyek praperadilan adalah tidak bersesuaian dengan metode penafsiran penghalusan hukum (rechtvervijning) maupun penafsiran ekstensif (extensieve interpretatie), karena KUHAP telah mengatur secara limitatif hal-hal yang menjadi kewenangan lembaga praperadilan dan tidak perlu dipersempit ataupun diperluas maknanya karena telah jelas dan dapat diterapkan pada peristiwa konkrit. Dengan penambahan "penetapan tersangka" sebagai unsur obyek norma (normgedrag) sistem Undang-Undang (sistem formal baru, sesungguhnya hakim praperadilan

10 Cica Aisyah, "Konstruksi Hukum”, http://www.cicajoli.com/2013/10/konstruksi-hukum.html, diakses 18 Maret 2016.

11 Liza Erwina, Penemuan Hukum Oleh Hakim, (Medan: FH. Universitas Sumatera Utara, 2002), hlm. 5. 
telah menggunakan metode interpretasi analogi (argumentum per analogiam) dalam pertimbangan hukumnya, yakni penafsiran sudah tidak berpegang pada aturan itu lagi, melainkan pada inti atau rasio dari aturan itu.

Penerapan metode interpretasi analogi demikian mengindikasikan bahwa hakim telah keluar dari asas legalitas, di mana atas dasar asas legalitas itulah penggunaan metode analogi tidak diperkenankan dalam lapangan hukum pidana. Menurut Logeman, bahwa hakim tidak diperkenankan menafsirkan undang-undang secara sewenang-wenang. Orang tidak boleh menafsirkan secara sewenang-wenang kaidah yang mengikat, hanya penafsiran yang sesuai dengan maksud pembuat undang-undang saja yang menjadi tafsiran yang tepat.

Pemaksaan penggunaan metode analogi dalam menemukan hukum di lapangan hukum pidana, baik hukum pidana materiil maupun hukum pidana formil dapat dianggap sebagai kesewenang-wenangan. Sehingga, apabila hakim praperadilan dianggap melakukan penemuan hukum yang memperluas makna dari bunyi Pasal 77 dan Pasal 95, terlihat betapa sangat tidak jelasnya metode yang digunakan. Jika dikatakan hakim praperadilan disebut telah menggunakan penafsiran ekstentif, justru tidak ditemukan ada unsur-unsur norma di dalam kedua pasal itu yang dijadikan titik tolak perluasannya. Jika dikatakan bahwa hakim praperadilan disebut menggunakan metode konstruksi, justru tidak ditemukan rasio yang mendukung penggunaan metode tersebut.
Selain ketidakjelasan metode penemuan hukum yang digunakan hakim praperadilan, putusan ini pun memuat pertimbangan yang memuat anggapan hakim praperadilan bahwa asas legalitas tidak berlaku untuk hukum acara pidana. Asas legalitas, menurut hakim, hanya berlaku untuk hukum pidana materiil seperti dalam pertimbangan yang berbunyi:

"Menimbang, bahwa tentang
penerapan azas legalitas dalam
Hukum Acara Pidana sebagai
salah satu dasar dan alasan dalam
mengajukan eksepsi ini tidak dapat
dibenarkan, karena azas legalitas
sebagaimana dimaksud dalam pasal
1 ayat (1) KUHP hanya berlaku
dalam penerapan Hukum Pidana
Materiil...".

Argumen dalam pertimbangan itu jelas tidak dapat diterima, karena dalam literatur pun telah diketahui 8 (delapan) prinsip legalitas sebagaimana diajarkan oleh Lon L. Fuller tentang inner morality of law, sepenuhya berbicara tentang ketentuan norma-norma hukum formil. Salah satu dari 8 (delapan) prinsip legalitas yang dikemukakan Lon L. Fuller adalah tentang larangan retroaktif; yang sangat sejalan dengan bunyi Pasal 1 ayat (1) KUHP.

Lagi pula, hukum acara pidana mengenal dan menganut asas legalitas sebagai pendamping bagi asas legalitas dalam hukum pidana materiil. Asas legalitas dalam hukum acara pidana Indonesia tidak saja tergambar dari konsideran KUHAP, namun secara eksplisit dinormakan dalam ketentuan Pasal 3 KUHAP yang menentukan bahwa peradilan 
dilakukan menurut cara yang diatur dalam undang-undang.

Menurut Andi Hamzah, ketentuan Pasal 3 KUHAP sepadan dengan Pasal 1 Strafvordering Belanda, yang mengatur mengenai asas legalitas dalam hukum acara pidana, sebagaimana berbunyinya: "strafvordering heef alleen plaats op de wijze bij wet voorzien" atau hukum acara pidana dijalankan hanya berdasarkan cara yang ditentukan oleh undang-undang. Dengan demikan adalah tidak benar hukum acara pidana tidak mengenal asas legalitas. Dalam bukunya Het Nederlandse Strafprocesrecht, ditegaskan oleh G. J. M. Corstens bahwa asas legalitas dalam hukum acara pidana sebagai nullum iudicium sine lege yang berarti "tidak ada keadilan tanpa hukum". ${ }^{12}$

Melalui asas legalitas dipahami, bahwa setiap tindakan aparat penegak hukum harus didasarkan pada undang-undang. Itu artinya, penegak hukum (termasuk hakim) tidak diperkenankan mengambil tindakan diluar apa yang telah ditentukan dalam undangundang, oleh karena undang-undang telah menentukan batas kewenangan praperadilan secara eksplisit dan limitatif, maka hakim tidak boleh bergerak dari kerangka rumusan undang-undang tersebut.

Hukum acara pidana memberikan kepastian hukum kepada individu dalam masyarakat, karena sesungguhnya hukum acara pidana menjamin keberlakuan hukum pidana secara tertib melalui suatu undangundang. Oleh karenanya, tidak dapat pula pembentuk atau pembuat undang-undang menciptakan suatu peraturan yang raguragu, tidak jelas, atau memberikan peluang penafsiran yang terlampau luas. Terlebih lagi bagi seorang hakim, walaupun di negara modern seperti saat ini tidak lagi menjadi corong undang-undang, tetapi hukum acara pidana membatasi secara ketat keinginankeinginan hakim untuk memperluas dan memaksakan diri melawan undang-undang hukum acara pidana dengan dalih apapun. Oleh karena itu, penemuan hukum dibidang hukum acara pidana menjadi amat sangat terbatas, jauh lebih terbatas dibandingkan dengan hukum pidana itu sendiri.

Secara a'contrario dapatlah diketahui bahwa hanya hal-hal yang telah ditetapkan secara limitatif dalam Pasal 1 angka 10, Pasal 77 sampai Pasal 82, dan Pasal 95 sampai Pasal 97 KUHAP sajalah yang dapat dimohonkan praperadilan, sedangkan peristiwa atau hal-hal yang tidak diatur (dalam hal ini sah atau tidaknya penetapan tersangka) berlaku sebaliknya atau tidak dapat dimohonkan praperadilan karena hal-hal yang tidak diatur tersebut bukan merupakan obyek praperadilan.

Bahkan dengan penafsiran sistematis terhadap beberapa pasal sebelumnya memperlihatkan bahwa praperadilan 
merupakan kewenangan pengadilan untuk menguji keabsahan tindakan penyidik atau penuntut umum yang berakibat pada pengurangan HAM seseorang khususnya penangkapan dan penahanan sebagai upaya paksa maupun penggeledahan, penyitaan, dan pemeriksaan surat. Jika tindakan tersebut terbukti dilakukan secara salah atau tidak sesuai dengan prosedur yang diatur oleh hukum, maka hukum memberi kompensasi dalam bentuk ganti rugi dan rehabilitasi. Tindakan yang berdampak pada pengurangan HAM tersebut dan dapat diuji hanyalah tindakan yang berupa upaya paksa. Yang termasuk upaya paksa adalah penangkapan, penahanan (vide Pasal 77), penggeledahan, penyitaan, dan pemeriksaan surat (vide Pasal 95). Dengan demikian jelas bahwa penetapan seseorang sebagai tersangka tidak dianggap sebagai salah satu upaya paksa. Dengan demikian jelas bahwa penetapan seseorang sebagai tersangka tidak dianggap sebagai salah satu upaya paksa. ${ }^{13}$

Penafsiran sejarah membawa pada proses penyusunan KUHAP, khususnya perdebatan ketika praperadilan itu akan diatur dalam KUHAP. Penyusun KUHAP ketika itu berbeda pendapat tentang apakah akan diatur rechter commissaris (hakim komisaris) sebagaimana yang ada di beberapa negara lain, sebagai alat kontrol terhadap penggunaan kekuasaan oleh penegak hukum. Sebagian pihak berpandangan bahwa pengaturan demikian akan memperlambat jalannya proses pemeriksaan perkara pidana, karena kondisi geografis Indonesia yang akan menyulitkan koordinasi antar penegak hukum dalam melakukan kekuasaannya (perlunya izin dari hakim komisaris untuk melakukan penangkapan, penahanan dan lainlain). Padahal proses peradilan yang lama ini merupakan salah satu kondisi yang hendak dirubah dengan penyusunan KUHAP.

Pilihan pembuat KUHAP jatuh pada praperadilan, dengan asumsi adanya kepercayaan bahwa penegak hukum Indonesia cukup profesional untuk tidak menggunakan kekuasaannya secara sewenang-wenang. Bila terjadi penggunaan kekuasaan secara sewenang-wenang atau salah secara prosedural, barulah sistem mengujinya melalui praperadilan. Oleh karenanya pengaturan praperadilan tidak hanya terkait dengan tindakan upaya paksa, tapi juga keputusan penyidik untuk menghentikan penyidikan dan keputusan penuntut umum untuk menghentikan penuntutan. Dengan kata lain, praperadilan kemudian juga sekaligus menjadi alat kontrol horizontal diantara penegak hukum dalam sistem peradilan pidana.

Penafsiran sejarah jelas mengungkapkan bahwa konsep habeas corpus tidak sepenuhnya diadopsi oleh praperadilan sebagaimana yang diatur dalam KUHAP saat ini. Konsep awal praperadilan dengan semangat habeas corpus

13 Lembaga Konsultasi Dan Bantuan Hukum (LKBH) Fakultas Hukum Universitas Andalas, "Hasil Eksaminasi Putusan Praperadilan Pengadilan Negeri Jakarta Selatan Nomor 04/Pid.Prap/2015/PN.Jkt.Sel.", (Padang: Universitas Andalas, 2015), hlm. 19. 
dikurangi kewenangannya oleh Pemerintah dan Dewan Perwakilan Rakyat (DPR) sehingga hanya berupa pengujian formal semata ${ }^{14}$ terhadap tindakan "upaya paksa" yang telah diatur secara terbatas.

Penafsiran teleologis berkenaan dengan tujuan diadakannya pranata hukum praperadilan ini. Dari sejarah penyusunan KUHAP serta tulisan beberapa ahli tentang praperadilan, termasuk keterangan ahli dalam pemeriksaan perkara ini, jelas bahwa ada 2 (dua) tujuan diaturnya praperadilan. Pertama untuk melindungi HAM tersangka/terdakwa, dan kedua sebagai alat kontrol horizontal antar penegak hukum dalam sistem peradilan pidana. Hal ini dimaksudkan agar terdapat proses hukum yang baik dan adil (due process of law) dalam sistem peradilan pidana di Indonesia. Namun harus disadari bahwa tujuan tersebut hanya dilakukan melalui pengujian secara prosedural, dalam arti keabsahan semua tindakan penegak hukum yang diatur dalam praperadilan, sebatas pengujian prosedur hukumnya. Praperadilan bukanlah peradilan yang mengadili perkara tindak pidana itu sendiri, atau memeriksa persoalan subtansi hukum dalam perkara pidana tersebut karena konsep awal praperadilan dengan semangat habeas corpus dikurangi kewenangannya oleh Pemerintah dan DPR sehingga hanya berupa pengujian formil semata, sehingga dapat dimaklumi bahwa pilihan pengaturan praperadilan ini juga dilatarbelakangi oleh situasi politik saat penyusunan KUHAP.
Dengan demikian diketahui bahwa berdasarkan penafsiran teleologis berkenaan dengan tujuan diadakannya pranata hukum praperadilan ini, yakni sebagai alat kontrol horizontal antar penegak hukum dalam sistem peradilan pidana melalui pengujian secara prosedural terhadap setiap tindakan penegak hukum dianggap tidak prosedural. Praperadilan bukanlah peradilan yang mengadili perkara tindak pidana itu sendiri, atau memeriksa persoalan subtansi hukum dalam perkara pidana tersebut.

Berdasarkan ketiga metode penafsiran tersebut, maka penetapan tersangka sebagai objek pemeriksaan praperadilan karena merupakan upaya paksa, adalah keliru dan telah melampaui batas kewenangan.

Penafsiran hukum hakim dengan memasukkan "penetapan tersangka" sebagai obyek praperadilan juga tidak bersesuaian dengan prinsip contextualism dalam interpretasi yang mendasarkan pendekatannya pada 3 (tiga) asas, yaitu asas Noscitur a Sociis, asas Ejusdem Generis dan asas Expressio Unius Exclusio Alterius. ${ }^{15}$

Dalam asas Noscitur a Sociis, suatu kata atau istilah harus diartikan dalam rangkaiannya dalam arti bahwa istilah itu harus dimaknai dalam kaitan associated-nya. Karena penetapan tersangka tidak termasuk ke dalam (associated with) rangkaian pengertian upaya paksa maka penetapan tersangka bukanlah objek praperadilan.

14 Institute for Criminal Justice Reform, Praperadilan di Indonesia: Teori, Sejarah dan Praktiknya, (Jakarta: ICJR, 2014), hlm. 47.

15 Putusan Mahkamah Konstitusi Nomor: 005/PUU-IV/2006, hlm. 83. 
Selanjutnya, memasukkan penetapan tersangka ke dalam ruang lingkup praperadilan juga tidak bersesuaian dengan asas Ejusdem Generis sebab menurut asas ini suatu kata atau istilah dibatasi maknanya secara khusus dalam kelompoknya. Praperadilan adalah istilah khusus atau tersendiri yang "diciptakan" dan khusus berlaku dalam penerapan KUHAP sehingga ruang lingkupnya pun tersendiri yaitu hanya mencakup tindakan-tindakan yang termasuk dalam kelompok upaya paksa.

Akhirnya, memasukkan penetapan tersangka ke dalam ruang lingkup praperadilan pun tidak bersesuaian dengan asas Expressio Unius Exclusio Alterius sebab menurut asas ini jika suatu konsep digunakan untuk satu hal maka konsep tersebut tidak berlaku untuk hal lain, misal konsep perbuatan melawan hukum dalam hukum pidana dan hukum perdata adalah berbeda. Terkait konteks putusan perkara a quo, konsep praperadilan adalah satu konsep tersendiri yang hanya digunakan oleh KUHAP yang ruang lingkupnya berkenaan dengan penggunaan upaya paksa dan akibat hukum yang berkait dengan penggunaan upaya paksa itu. ${ }^{16}$

3. Pertimbangan hakim bahwa Pemohon bukanlah subyek hukum pelaku tindak pidana korupsi yang menjadi kewenangan KPK (Termohon) juga tidak mengandung argumentasi yang cukup. Jika hakim menelusuri secara menyeluruh ketentuan perundang-undangan untuk memastikan terdapat motivering vonis, maka pengertian "aparat penegak hukum" dapat ditemukan dalam Penjelasan Pasal 5 ayat (1) Undang-Undang Nomor 18 Tahun 2003 tentang Advokat, Pasal 2 Undang-Undang Nomor 2 Tahun 2002 tentang Kepolisian Negara Republik Indonesia, Penjelasan Pasal 101 ayat (6) Undang-Undang Nomor 8 Tahun 1995 tentang Pasar Modal, Penjelasan Pasal 49 ayat (2) huruf i Undang-Undang Nomor 21 Tahun 2011 tentang Otoritas Jasa Keuangan dan Pasal 4 KUHAP.

Logika atau penalaran silogisme kategoris yang dapat ditarik dari bunyi pasal dan penjelasan atas pengertian "aparat penegak hukum" dari ketentuan peraturan perundangundangan diatas adalah:

Tiap polisi adalah penyelidik. Penyelidi/k adalah penegak hukum. Pemohon adalah polisi. Pemohon adalah penyelidik dan penegak hukum.

4. Dalam pertimbangan selanjutnya dalam memaknai "tindak pidana korupsi yang mendapat perhatian meresahkan masyarakat", argumentasi hakim praperadilan adalah: ${ }^{17}$

Menimbang bahwa saat Pemohon menjabat sebagai Karo Binkar, masyarakat sama sekali tidak mengenal Pemohon, dan masyarakat baru mengenal Pemohon saat Pemohon ditetapkan sebagai calon tunggal Kapolri oleh Presiden 
Republik Indonesia, dan saat Pemohon ditetapkan sebagai Tersangka oleh Termohon, tepat sehari sebelum Pemohon mengikuti fit and proper test di DPR, sehingga kualifikasi mendapat perhatian yang meresahkan masyarakat sebagaimana dimaksud dalam pasal 11 huruf $b$ Undang-Undang KPK pun tidak terpenuhi.

Secara gramatikal/tata bahasa, kriteria Pasal 11 huruf b Undang-Undang Nomor 30 Tahun 2002 tentang Komisi Pemberantasan Tindak Pidana Korupsi mengacu kepada tindak pidana, sebab yang mendapat penjelasan dari frasa "yang mendapat perhatian meresahkan masyarakat" itu adalah frasa "tindak pidana korupsi", bukan "pelaku tindak pidana korupsi". Hakim seharusnya memahami bahwa perkara tindak pidana korupsi yang diduga dilakukan oleh pemohon dalam perkara a quo, termasuk ke dalam "kasus rekening gendut" perwira tinggi Kepolisian RI, yang mulai mengemuka pada tahun $2010 .{ }^{18}$

Dengan demikian, berdasarkan analisis terhadap logika hukum hakim praperadilan sebagaimana tersebut di atas, maka aspek keadilan dan kepastian hukum dari putusan perkara a quo adalah sebagai berikut:

1. Terkait aspek keadilan, dalam proses pemeriksaan perkara pidana, prosedur pemeriksaan perkara pidana melalui tahapan-tahapan pemeriksaan. Pada tahapan pertama dikenal sebagai keadilan prosedural (procedural justice).
Pada bagian ini dituntut ditegakkannya asas-asas hukum. Bagian kedua adalah keadilan substansial (substantial justice) yang bergantung kepada keadilan yang pertama. Artinya jika prosedurnya yang adil yang diatur dalam hukum acara pidana atau hukum pidana formil sudah ditegakkan, merupakan prasyarat terwujudnya keadilan substansial yang diatur dalam hukum pidana materiil, sebaliknya prosedur yang tidak adil tidak dapat melahirkan keadilan substansial. ${ }^{19}$ Dalam perkara a quo, hakim praperadilan seolah-olah hendak mewujudkan keadilan substansial dengan memasukkan "penetapan tersangka" sebagai unsur objek norma (normgedrag) baru dalam rangkaian Pasal 77 huruf a KUHAP menjadi kewenangan praperadilan dengan mengabaikan keadilan prosedural yang menuntut penegakan terhadap asasasas hukum dalam penggunaan metode interpretasi di pertimbangan hukumnya. Asas-asas hukum tersebut meliputi asas Noscitur a Sociis, asas Ejusdem Generis dan asas Expressio Unius Exclusio Alterius yang merupakan asas yang terkandung dalam prinsip contextualism.

2. Terkait aspek kepastian hukum, dapat dikemukakan bahwa putusan perkara $a$ quo selain tidak sesuai dengan asas yang terkandung dalam prinsip contextualism, juga bertentangan dengan asas legalitas

18 Lembaga Konsultasi Dan Bantuan Hukum (LKBH) Fakultas Hukum Universitas Andalas, op.cit., hlm. 28.

19 Badan Pembinaan Hukum Nasional, Hakim Komisaris dalam Sistem Peradilan di Indonesia, (Jakarta: BPHN, 2011), hlm. 2-3. 
yang terkandung dalam Pasal 3 KUHAP. Hal ini dikarenakan hakim praperadilan telah melakukan analogi terhadap kewenangan lembaga praperadilan dengan menetapkan "penetapan tersangka" sebagai unsur obyek norma (normgedrag) baru didalamnya. Putusan a quo akan mengganggu kepastian hukum dalam tatanan sistem hukum karena terdapat suatu konstruksi hukum baru yang tidak sesuai secara penalaran metode argumentum a'contrario terhadap rujukan dalam Pasal 77 huruf a KUHAP dan hal tersebut bertentangan dengan asas legalitas dalam lapangan hukum pidana.

Selain itu, dikaji dari interpretasi sistematis, interpretasi sejarah dan interpretasi teleologis terkait pengaturan ruang lingkup kewenangan lembaga praperadilan di Indonesia, maka tidak dapat dibenarkan logika hukum hakim praperadilan dalam pertimbangan perkara a quo yang menciptakan unsur obyek norma (normgedrag) baru sebagai kewenangan lembaga praperadilan dengan metode interpretasi analogi (argumentum per analogiam).

\section{Simpulan}

Berdasarkan pembahasan yang telah diuraikan, dapatlah disimpulkan bahwa eksistensi Putusan Praperadilan Nomor: 04/ Pid.Prap/2015/PN.Jkt.Sel., tidak mencermin kan prinsip keadilan dan kepastian hukum.
Hakikat pemeriksaan permohonan praperadilan sesungguhnya adalah pemeriksaan yang bersifat pemenuhan syarat formalitas, karena lembaga praperadilan tidak memeriksa pokok perkara suatu perkara pidana. Ketidakpatuhan terhadap asasasas hukum dengan tanpa memperhatikan kesesuaian dengan hukum (rechmatigheid) dalam membuat pertimbangan hukum suatu putusan pemeriksaan perkara pidana termasuk permohonan praperadilan akan mencederai perasaan keadilan dari hukum itu sendiri.

Penegakan asas-asas hukum secara baik dengan penggunaan metode interpretasi yang tepat dalam logika hukum pertimbangan hakim praperadilan akan menjamin kepastian hukum dari suatu putusan. Dalam putusan pidana, penerapan asas legalitas seperti yang dianut dalam Pasal 3 KUHAP merupakan prasyarat penting, selain itu harus diperhatikan bahwa tidak diperkenankannya penggunaaan metode interpretasi analogi dalam lapangan hukum pidana.

Oleh karenanya, guna mengantisipasi dampak dari Putusan Praperadilan Nomor: 04/ Pid.Prap/2015/PN.Jkt.Sel., Mahkamah Agung RI perlu menggunakan fungsi pengawasannya untuk memastikan setiap hakim mematuhi hukum acara pidana guna terjaminnya prinsip keadilan dan kepastian hukum dalam putusan yang dikeluarkan. Dan bagi pembentuk undang-undang (Pemerintah dan DPR) untuk secepatnya merevisi ketentuan tentang praperadilan yang diatur dalam KUHAP. 


\section{DAFTAR PUSTAKA}

\section{Buku}

Badan Pembinaan Hukum Nasional. Hakim

Komisaris dalam Sistem Peradilan di Indonesia, Jakarta: BPHN, 2011.

Erwina, Liza. Penemuan Hukum Oleh Hakim.

Medan: FH. Universitas Sumatera Utara, 2002.

Institute for Criminal Justice Reform. Praperadilan Di Indonesia: Teori, Sejarah dan Praktiknya. Jakarta: ICJR, 2014.

Januar, Wahyu. Studi Komparatif Hukum Wewenang Dan Fungsi Praperadilan Menurut Hukum Acara Pidana Indonesia Dengan Sistem Habeas Corpus Di Amerika Serikat. Surakarta: FH. Universitas Sebelas Maret, 2011. Lembaga Konsultasi Dan Bantuan Hukum (LKBH) Fakultas Hukum Universitas Andalas. "Hasil Eksaminasi Putusan Praperadilan Pengadilan Negeri Jakarta Selatan Nomor 04/Pid. Prap/2015/PN.Jkt.Sel.”. Padang: Universitas Andalas, 2015.

Meliala, Nefa Claudia. Upaya Pembaharuan Hukum Acara Pidana Nasional Melalui Hakim Komisaris Sebagai Pengganti Praperadilan. Jakarta: FH. Program Pasca Sarjana Universitas Indonesia, 2012.

Sari, Dian Novita. Pengajuan Praperadilan Oleh Pihak Tersangka Terhadap Sah Atau Tidaknya Penahanan Yang
Dilakukan Penyidik Kejaksaan Dalam Tindak Pidana Korupsi (Studi Putusan Nomor.01/PID/PRA.PER/2011/ PN.STB.). Medan: FH. Universitas Sumatera Utara, 2012.

Septiana, Beatrik Dwi, dkk. Upaya Hukum Atas Putusan Praperadilan Yang Melampaui Kewenangan Lembaga Praperadilan (Studi Kasus Putusan Pengadilan Negeri Jakarta Selatan Nomor: 38/Pid.Prap/2012/PN.Jkt.Sel., Atas Nama Bachtiar Abdul Fatah). Jakarta: FH. Universitas Indonesia, 2013.

\section{Jurnal}

Sapardjaja, Komariah Emong. "Kajian dan Catatan Hukum Atas Putusan Pra-peradilan Nomor 04/Pid.Prap/2015/ PN.Jkt.Sel Tertanggal 16 Februari 2015 Pada Kasus Budi Gunawan: Sebuah Analisis Kritis", Jurnal Ilmu Hukum Vol. 2 No. 1 Tahun 2015, Bandung: Universitas Padjadjaran, 2015.

\section{Peraturan Perundang-undangan}

Putusan Mahkamah Konstitusi Nomor: 005/ PUU-IV/2006.

Putusan Mahkamah Konstitusi Nomor: 21/ PUU-XII/2014.

Putusan Pengadilan Negeri Jakarta Selatan Nomor: 04/Pid.Prap/2015/PN.Jkt.Sel. tentang Penetapan Tersangka. 


\section{Naskah Internet}

Fadilah, Dila. "Penafsiran Dan Cara Mengisi Kekosongan Hukum". http://aboutdila. blogspot.co.id/2014/03/penafsirandan-cara-mengisi-kekosongan.html, diakses 03 Pebruari 2016. 